\title{
Analysis of longevity in Suffolk sheep in the Czech Republic1)
}

\author{
MICHAL MILERSKI, LUDMILA ZAVADILOVÁ, JITKA SCHMIDOVÁ, \\ ANDRZEJ JUNKUSZEW*, WIKTOR BOJAR*
}

\author{
Institute of Animal Science, Prague - Uhříněves, 10400 \\ *Institute of Animal Breeding and Biodiversity Conservation, \\ University of Life Sciences in Lublin, Akademicka 13, 20-950 Lublin
}

\section{Milerski M., Zavadilová L., Schmidová J., Junkuszew A., Bojar W. Analysis of longevity in Suffolk sheep in the Czech Republic}

\section{Summary}

The objectives of this study were to evaluate systematic factors that influence longevity and to estimate the heritability of functional longevity by survival analysis of Suffolk sheep in the Czech Republic. A total of 20,502 ewes from 137 flocks were used. The longevity of Suffolk ewes was influenced to some extent by their average prolificacy. The effects of growth intensity and the development of muscularity and fattiness, as well as the effect of the prion protein gene PrP haplotype on the risk of the exclusion of the ewe from breeding were relatively low. Heritability estimates were $h^{2}=0.438$ for the length of production life in days $(L P L), h^{2}=0.098$ for the number of litters of the ewe during her lifetime (NL), $\mathbf{h}^{2}=\mathbf{0 . 1 1 1}$ for the total number of lambs born (TLB), and $h^{2}=0.103$ for the total number of labs weaned (TLW). Correlations between the breeding values for LPL and NL, TLB or TLW were high. Therefore, these indicators of the ewe's lifelong production, which are more desirable and understandable for sheep breeders, should be used in indirect selection for longevity.

Keywords: longevity, sheep, Suffolk

The increasing of functional longevity could rationalize animal production systems by reducing the need to carry non-productive replacement livestock and by limiting costs due to the health problems of animals. Longevity is affected by many genetic and environmental factors as well as by management decisions. Nevertheless, health-related factors play a key role in this respect. Healthy and disease-resistant animals have prospects for a longer production life. This is also the case in sheep. For instance, Legarra et al. (8) and Barillet et al. (1) reported a significant impact of clinical and subclinical mastitis, predicted by somatic cell count, on the culling of ewes. Gastrointestinal parasite infections, as well, often cause life shortening in sheep $(12,15)$. Unfortunately, the records of health and the reason for culling in sheep are often unavailable in databases, and in this case the evaluation of animal longevity is one of few possibilities to genetically improve the health status of sheep populations by breeding. Longevity is therefore an economically

1) This study was supported by the National Agency for Agricultural Research of the Czech Republic and the Ministry of Agriculture of the Czech Republic Prague (projects no. QJ1510144, MZE RO0718). important trait, but only little research has been devoted to the economic value of longevity in sheep. The published results are not consistent. In fact, Fuerst-Waltl and Baumung (5) reported a slightly negative economic value for this trait. In the Czech population of the Suffolk sheep breed, Wolfová et al. $(20,21)$ found the relative economic value for longevity to be $3.13 \%$ in the case of pure-breeding and $2.78 \%$ when Suffolk rams were used as sires in terminal crossing. In dairy sheep, Wolfová et al. $(18,19)$ reported an economic value of $11.1 €$ for prolongation of life by one year per one ewe in an average-sized flock. The economic value of longevity in sheep is highly dependent on the cost of replacement and the price of culled animals. Both of them are far lower in sheep compared with cattle (especially the dairy type). Genetic gain in population and the productivity of animals, which decreases with age, should also be taken into account. Higher longevity is connected with a greater average age of the breeding ewe flock and a longer generation interval, and thus theoretically with slower genetic progress. Longevity is also reported to be one of the lowly heritable traits. The heritability estimate for functional longevity found 
in Valle del Belice sheep by Riggio et al. (14) was 7\% on the logarithmic scale and $11 \%$ on the real scale, indicating that selection for this trait is possible in sheep. The flock-year-season effect explained $19 \%$ of the variation on the logarithmic scale and $27 \%$ of the variation on the real scale. In their study, Fuerst-Waltl et Baumung (5) estimated the heritability of functional longevity at $h^{2}=0.12$. Another limitation is that longevity is impossible to measure in young animals, and therefore it cannot be bred for directly (2). On the other hand, a favourable factor for longevity evaluation in sheep is the ready availability of basic records regarding the length of production life in databases of the performance recording scheme. However, sheep longevity has not yet been evaluated in practice in breeding programmes in the Czech Republic.

The main aims of this study were therefore to analyze selected systematic factors influencing longevity and to estimate genetic parameters for traits connected with life expectancy in Suffolk sheep - the most numerous recorded sheep population in the Czech Republic.

\section{Material and methods}

The study used a database of the official performance recording scheme provided by the Association of Sheep and Goat Breeders in the Czech Republic containing primarily records of 20,502 ewes (including 5301 censored records of living individuals) from 137 flocks. However, only parts of this database were used for individual analyses. The analysis of survivability was performed by non-linear hazard functions, using the Survival Kit program package (3). The basic model equation included the class effects of the flock (137 levels of effect), the birth year of the ewe (27), the year of the last lambing (22) and the age at first lambing (3 classes). Subsequently, further effects were added individually to this basic model: the size of the litter from which the ewe originated (4 classes: 1, 2, 3, 4 and more lambs in litter), the average prolificacy of ewes (4 classes: 0 - without records, $1-100-125 \%, 2->125-175 \%, 3->175 \%)$, weight at 100 days ( 3 classes: $\leq 25 \mathrm{~kg},>25-37.5 \mathrm{~kg},>37.5 \mathrm{~kg}$ ), backfat thickness measured by ultrasound ( 6 classes: 1, 2, 3, 4, 5, 6 and more $\mathrm{mm}$ ), eye-muscle depth measured by ultrasound ( 3 classes: $\leq 21 \mathrm{~mm}, 22-31 \mathrm{~mm}, 32$ and more $\mathrm{mm}$ ), subjective assessment of muscularity in the live animal (5 classes), and the PrP genotype (5 haplotypes: ARQ/ARQ, ARR/ARH, ARR/ARQ, ARR/ARR, ARQ/VRQ).

Genetic parameters were estimated for 4 traits associated with longevity: the length of the production life from the first to the last lambing of the ewe in days (LPL), the number of litters during lifetime (NL), the total number of lambs born (TLB) and the total number of lambs weaned (TLW).

Genetic parameters for LPL were estimated by the Weibull model, For NL, TLB and TLW, the Prentice and Gloeck model was used. Model equations for LPL and NL contained effects of the herd, year of birth, year of exclusion from the heard and the class of age at first lambing. To estimate genetic parameters for TLB and TLW, the fixed effects of the herd, the year of birth and the class of age at first lambing were included into the model equations.

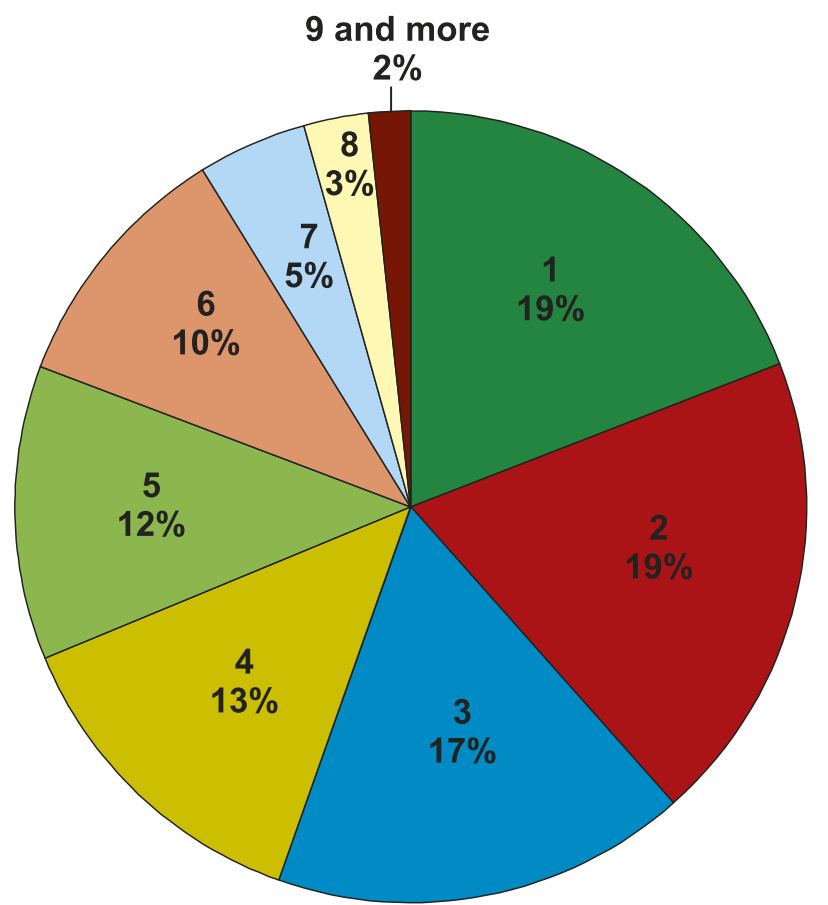

Fig. 1. Percentages of ewes according to the lifetime number of litters produced before exclusion from breeding

\section{Results and discussion}

Fig. 1 shows the percentage of ewes according to the lifetime number of litters produced. Only uncensored records of ewes already excluded from recorded flocks were used. It can be seen that many ewes produced only a few litters during their production life span. The most intensive culling of ewes occurred between the $6^{\text {th }}$ and $7^{\text {th }}$ litter $(57.4 \%)$. The maximum number of litters was 14 .

In Tab. 1-7, the levels of the risk of culling are listed for individual factors, and the figures are relative to the most numerous class within the factor, for which the risk of culling was set to 1.000 .

The average prolificacy of ewes significantly influenced the risk of their exclusion from the herd, and thus their longevity (Tab. 1). In the group of ewes without records on litter size, the risk of culling was obviously high. It is likely that many of these ewes were culled at an early age because of reproduction problems. The risk was also relatively higher in the class of ewes with the lower average prolificacy, probably because of negative selection by the breeder. The risk in the class with the highest prolificacy was also slightly higher, which could be explained by the higher physiological stress on the animal's organism and the higher ratio of lambing problems and/or postpartum complications in highly prolific ewes. Similar trends have been observed in Dorset sheep by McLaren (10), who found a moderate negative genetic correlation $r_{g}=-0.4$ between longevity and litter size. This suggests that a larger litter size in Dorsets could lead to a shorter lifespan. It was not the case for Lleyn sheep. The genetic correlation between longevity and the age at first lambing was high, especially in Dorsets $r_{g}=0.8$. This suggests 
Tab. 1. Risk of culling according to the average prolificacy of ewes

\begin{tabular}{|l|c|c|c|c|}
\hline Average prolificacy & No record & $\leq 125 \%$ & $>125-175 \%$ & $>175 \%$ \\
\hline Risk of culling & 5.874 & 2.060 & 1.000 & 1.248 \\
\hline N & 738 & 3842 & 4729 & 4462 \\
\hline
\end{tabular}

Tab. 2. Risk of culling according to the size of the litter from which the ewe originated

\begin{tabular}{|l|c|c|c|c|}
\hline \multicolumn{1}{|c|}{ Litter size } & 1 & 2 & 3 & $\geq 4$ \\
\hline Risk of culling & 1.058 & 1.000 & 0.983 & 1.359 \\
\hline N & 4434 & 8119 & 1039 & 43 \\
\hline
\end{tabular}

Tab. 3. Risk of culling according to the weight of the ewe at 100 days of age

\begin{tabular}{|l|c|c|c|}
\hline \multicolumn{1}{|c|}{ Weight at 100 days } & $\leq 25 \mathrm{~kg}$ & $>25-37.5 \mathrm{~kg}$ & $>37.5 \mathrm{~kg}$ \\
\hline Risk of culling & 1.124 & 1.000 & 0.974 \\
N & 2857 & 7818 & 827 \\
\hline
\end{tabular}

Tab. 4. Risk of culling according to eye-muscle depth measured by ultrasound at 100 days of age

\begin{tabular}{|l|c|c|c|}
\hline \multicolumn{1}{|c|}{ Eye-muscle depth } & $\leq 21 \mathrm{~mm}$ & $22-31 \mathrm{~mm}$ & $\geq 32 \mathrm{~mm}$ \\
\hline Risk of culling & 1.174 & 1.000 & 0.952 \\
N & 851 & 4254 & 302 \\
\hline
\end{tabular}

Tab. 5. Risk of exclusion from flock according to subjective assessment of muscularity at $\mathbf{1 0 0}$ days of age

\begin{tabular}{|l|c|c|c|c|c|}
\hline \multicolumn{1}{|c|}{ Class of muscularity } & 1 & 2 & 3 & 4 & 5 \\
\hline Risk of exclusion from flock & 1.299 & 1.077 & 1.076 & 1.066 & 1.000 \\
\hline N & 24 & 214 & 1429 & 2106 & 2117 \\
\hline
\end{tabular}

Tab. 6. Risk of culling according to backfat thickness measured by ultrasound at $\mathbf{1 0 0}$ days of age

\begin{tabular}{|l|c|c|c|c|c|c|}
\hline Backfat thickness & $1 \mathrm{~mm}$ & $2 \mathrm{~mm}$ & $3 \mathrm{~mm}$ & $4 \mathrm{~mm}$ & $5 \mathrm{~mm}$ & $\geq 6 \mathrm{~mm}$ \\
\hline Risk of culling & 1.224 & 1.016 & 1.000 & 0.887 & 0.904 & 0.836 \\
N & 81 & 669 & 2338 & 1934 & 740 & 205 \\
\hline
\end{tabular}

Tab. 7. Risk of culling according to the haplotype of the prion protein gene PrP

\begin{tabular}{|l|c|c|c|c|c|}
\hline PrP haplotype & ARQ/ARQ & ARR/ARH & ARR/ARQ & ARR/ARR & ARQ/NRQ \\
\hline Risk of culling & 1.059 & 1.421 & 1.065 & 1.000 & 1.307 \\
N & 300 & 31 & 1538 & 2223 & 52 \\
\hline
\end{tabular}

Tab. 8. Coefficients of heritability (on diagonal), correlations between breeding values for individual traits (above diagonal) and phenotype correlations between residuals after adjustment for non-genetic effects (below diagonal)

\begin{tabular}{|l|c|c|c|c|}
\hline \multicolumn{1}{|c|}{ Trait } & LPL & NL & TLB & TLW \\
\hline LPL & 0.438 & 0.806 & 0.787 & 0.748 \\
NL & 0.884 & 0.098 & 0.771 & 0.742 \\
TLB & 0.845 & 0.849 & 0.111 & 0.897 \\
TLW & 0.815 & 0.828 & 0.934 & 0.103 \\
\hline
\end{tabular}

Explanations: LPL - length of production life from first to last lambing in days, NL - number of litters during lifetime (NL), TLB - total number of lambs born, TLW - total number of lambs weaned that the lambing of one-year-old ewe lambs may lead to a shorter life span and confirms the assumption that a more intensive production of animals is likely to have a negative impact on their longevity.

The number of siblings of the ewe in the litter had a negligible effect on the risk of her future elimination from breeding (Tab. 2). The highest risk was found for ewes from multiple litters (4 and more lambs in litter), whose development during rearing may have been poorer because of food competition between lambs within the litter. It is also possible that the prolificacy of these animals was higher, which put a greater burden on their organism and had a negative impact on their longevity, as mentioned above. In any case, the group of ewes originating from such multiple litters was not numerous.

The effect of the weight of ewes at 100 days of age on their longevity was not significant (Tab. 3). Nevertheless, individuals with a higher growth intensity seem to be slightly more beneficial in that matter. The same tendency is revealed by data on the depth of eye-muscle measured by ultrasound behind the last rib (Tab. 4) and the subjective assessment of muscularity in live animals using a 5-point scale (Tab. 5). Differences between the classes are not significant, but animals with better muscular development tend to have a longer period of production life.

The risk of culling also tends to decrease slightly with increasing backfat thickness measured by ultrasound at the age of 100 days (Tab. 6). From obtained results is not apparent the eventual and probable risk of negative influencing of animal health or longevity by too intensive rearing connected with high fattiness. It is also possible that a positive genetic correlation exists between backfat thickness and eye-muscle depth reported in a Suffolk sheep population by Maxa et al. (9) and associated with selection carried out by the breeder.

A higher risk of elimination from breeding was found for ewes with haplotypes ARR/ARH and ARQ/VRQ in the prion protein gene PrP connected with resistance to scrapie (Tab. 7). Nevertheless, these are minority haplotypes, whose frequencies in the Czech Suffolk population were reduced by the national programme for genetic improvement of resistance to scrapie (16).

Tab. 8 lists the coefficients of heritability of traits associated with longevity and correlations between them. The heritability of LPL was significantly higher compared to the findings of Riggio et al. (14) or Fuerst-Waltl and Baumung (5). Also McLaren et al. (10) reported the heritability of longevity to be $7 \%$ in Lleyn sheep and 11\% in Dorset sheep. Hatcher et al. (6) found that the heritability of survival in adult Merino ewes, both within ages and cumulative, was negligible at 2 years of age, but tended to increase with increasing age. The heritability of cumulative survival increased from 0 at 2 years of age to 0.13 at 5 years of age. The fact that heritability estimates for cumula- 
tive survival increase with age suggests that longevity genes determine survival in adult sheep.

Correlations between breeding values for individual traits were high, which suggests the possibility of their alternative use in breeding programmes in sheep. According to Essl (4), artificial selection for production traits should generally lead to a deterioration in longevity. This has been demonstrated in dairy cattle, in which selection for production traits resulted in negative correlated responses in fitness and longevity traits $(4,13,17)$. Also type traits in cattle are correlated with longevity $(11,22-24)$. There is less information on this topic for sheep. Nevertheless, Hatcher and Atkins (7) found that phenotypic selection for high clean fleece weight in Merino sheep leads to fewer progeny surviving to weaning. In any case, selection for production traits should be accompanied by selection for longevity or at least by the monitoring thereof.

Longevity is a trait that is potentially usable in sheep breeding programmes in the Czech Republic. Appropriate data containing the additive genetic component are available for traits associated with longevity. There are some indications that intensive breeding for production traits may negatively affect longevity. It is therefore advisable that individuals selected for breeding should be able to provide high production for a long time. High correlations between breeding values for traits associated with longevity makes it possible to use cumulative lifelong production traits, such us the total number of lambs weaned, in indirect selection for longevity.

\section{References}

1. Barillet F., Rupp R., Mignon-Grasteau S., Astruc J. M., Jacquin M.: Genetic analysis for mastitis resistance and milk somatic cell score in French Lacaune dairy sheep. Genet. Sel. Evol. 2001, 33, 397-415.

2.Byun $S$. $O$.: Genes associated with variation in longevity and fecundity in sheep. Ph.D. thesis. Lincoln University. New Zealand 2012, p. 226.

3. Ducrocq V., Sölkner J.: „The Survival Kit” a FORTRAN package for the analysis of survival data, [in:] $5^{\text {th }}$ World Cong. Genet. Appl. Livest. Prod. 1994, 22, 51-52.

4. Essl A.: Longevity in dairy cattle breeding: a review. Livest. Prod. Sci. 1998, 57, 79-89.

5. Fuerst-Waltl B., Baumung R.: Economic values for performance and functional traits in dairy sheep. Ital. J. Anim. Sci. 2009, 8, 341-357.

6. Hatcher S., Atkins K. D.: Does phenotypic selection for fleece weight reduce lamb survival? Proc. Assoc. Advmt. Anim. Breed. Genet. 2007, 17, 56-564.

7. Hatcher S., Atkins K. D., Thornberry K. J.: Survival of adult sheep is driven by longevity genes. Proc. Assoc. Advmt. Anim. Breed. Genet. 2009, 18, 580-583 .

8. Legarra A., Ramón M., Ugarte E., Pérez-Guzmán M. D., Arranz J.: Economic weights of somatic cell score in dairy sheep. Animal 2007, 1, 205-212.

9. Maxa J., Norberg E., Berg P., Milerski M.: Genetic parameters for body weight, longissimus muscle depth and fat depth for Suffolk sheep in the Czech Republic. Small Rumin. Res. 2007, 72, 87-91.

10. McLaren A., Mucha S., Kaseja K., Moore K., Conington J.: Ewe longevity as a breeding goal in sheep breeding programmes. [online] 2015. Available from: http://www.nationalsheep.org.uk/workspace/pdfs/coningtonjo 22112015101634.pdf

11. Novotný L., Frelich J., Beran J., Zavadilová L.: Genetic relationship between type traits, numbers of lactations initiated and lifetime milk performance in Czech Fleckvieh Cattle. Czech J. Anim. Sci. 2017, 62, 501-510.

12. Perry B. D., Randolph T. F.: Improving the assessment of the economic impact of parasite diseases and their control in production animals. Vet. Parasitol. $1999,84,145-168$
13. Pritchard T., Coffey M., Mrode R., Wall E.: Understanding the genetics of survival in dairy cows. J. Dairy Sci. 2013, 96, 3296-3309.

14. Riggio V., Portolano B., Bovenhuis H., van Arendonk J. A. M.: Effect of somatic cell count level on functional longevity in Valle del Belice dairy sheep assessed using survival analysis. J. Dairy Sci. 2008, 92, 6160-6166.

15.Schallig H. D. F. H., van der Aar W. M., Boersema J. H., Cornelissen A. W. C. A.: The effect of oxfendazole terminated infections with Haemonchus contortus on the development of immunity in sheep. Vet. Parasitol. 2000, 88, 61-72.

16. Štépánek O., Hořin P.: Genetic diversity of the prion protein gene (PRNP) coding sequence in Czech sheep and evaluation of the national breeding programme for resistance to scrapie in the Czech Republic. J. Appl. Genet. 2017, 58, 111-121

17. Wall E., Brotherstone S., Coffey M. P.: Development of a robustness index for UK dairy cattle. In Proc. $8^{\text {th }}$ World Congr. Genet. Appl. Livest. Prod. 2006, Belo Horizonte, Minas Gerais, Brazil.

18. Wolfová M., Wolf J., Krupová Z., Kica J.: Estimation of economic values for traits of dairy sheep: I. model development. J. Dairy Sci. 2009, 92, 2183-2194.

19. Wolfová M., Wolf J., KrupováZ., Margetín M.: Estimation of economic values for traits of dairy sheep: II. model application to a production system with one lambing per year. J. Dairy Sci. 2009, 92, 2195-2203.

20. Wolfová M., Wolf J., Milerski M.: Calculating economic values for growth and functional traits in non-dairy sheep. J. Anim. Breed. Genet. 2009, 126, 480-491.

21. Wolfová M., Wolf J., Milerski M.: Economic weights of production and functional traits for Merinolandschaf, Romney, Romanov and Sumavska sheep in the Czech Republic. Small Rumin. Res. 2011, 99, 25-33.

22. Zavadilová L., Němcová E., Štípková M., Bouška J.: Relationships between longevity and conformation traits in Czech Fleckvieh cows. Czech J. Anim. Sci. 2009, 54, 387-394.

23. Zavadilová L., Štipková M., Němcová E., Bouška J., Matějičková J.: Analysis of the phenotypic relationships between type traits and functional survival in Czech Fleckvieh cows. Czech J. Anim. Sci. 2009, 54, 521-531.

24. Zavadilová L., Śtípková M.: Genetic correlations between longevity and conformation traits in the Czech Holstein population. Czech J. Anim. Sci. 2012, $57,125-136$

Corresponding author: Michal Milerski, PhD, Genetics and Animal Breeding, Institute of Animal Science, Přátelství 815, 10400 Prague Uhř́něves, Czech Republic; e-mail: milerski.michal@vuzv.cz 